\title{
Komunikasi Informasi dan Edukasi (KIE) pada Santri tentang Peningkatan Imunitas untuk Pencegahan COVID-19
}

\author{
Nur Lina ${ }^{1}$, Siti Novianti' ${ }^{1}$, Andik Setiyono ${ }^{1}$, Depi Setialesmana ${ }^{2}$ \\ 1. Prodi Kesehatan Masyarakat Universitas Siliwangi \\ 2. Prodi Pendidikan Matematika Universitas Siliwangi
}

\begin{abstract}
ABSTRAK
Pendahuluan: Corona virus Disease 2019 (Covid-19) adalah penyakit yang disebabkan SARS-CoV-2. Muncul Klaster Covid-19 di Pesantren Kota Tasikmala. Hal-hal yang meningkatkan risiko penularan Covid-19 di pondok pesantren diantaranya, satu kamar diisi lima sampai belasan santri sehingga menyulitkan prinsip jaga jarak yang menjadi bagian protokol kesehatan. Tujuan kegiatan Pengabdian Masyarakat Skema Kesehatan (PbM-SK) adalah mencegah Covid-19 di pesantren melalui kegiatan Komunikasi Informasi dan Edulasi (KIE) pada santri tentang peningkatan imunitas untuk pencegahan infeksi Covid-19.

Metode: Metode PbM-SK yang digunakan adalah pemberdayaan masyarakat pesantren melalui KIE yang dilakukan pada dua mitra yaitu Pesantren Persis Benda 66 dan Pesantren Ibadurrahman. Kegiatan KIE di Pesantren Benda 66 dilakukan pada tanggal 28 Juli 2021 dengan jumlah peserta sebanyak 150 orang sedangkan kegiataan di Pesantren Ibadurrahman dilaksanakan pada tanggal 16 Agustus 2021 dengan jumlah peserta sebanyak 30 orang.

Hasil dan pembahasan: Pemberian KIE tentang peningkatan imunitas untuk pencegahan Covid-19 di Pesantren Ibadurrahman dilaksanakan pada siswa MTs dan MA putra dan putri yang dilaksanakan bersamaan dengan kegiatan TOP (Taaruf Orientasi Pesantren) pada santri baru kelas satu. Pengelola pesantren didorong terlibat pro aktif dan berkoordinasi dengan pelayanan kesehatan dalam pemberian vaksinasi pada santri. Kedua mitra diberikan Kit Pencegahan Covid-19 yaitu masker kain, masker bedah, hand sanitizer, oksimeter, vitamin C. Diberikan juga banner sebagai media edukasi, untuk menjadi pengingat agar tetap patuh protokol kesehatan.

Kesimpulan: Pelaksanaan KIE berjalan dengan lancar, peserta menyimak dengan antusias. Telah disampaikan alat kesehatan berupa masker kain dan masker bedah, hand sanitizer dan oksimeter dan vitamin.
\end{abstract}

Kata Kunci : KIE; Covid-19; Pesantren

\begin{abstract}
Introduction: Coronavirus Disease 2019 (Covid-19) is a disease caused by SARS-CoV-2. Covid-19 Cluster appeared in Tasikmala City Pesantren. Things that increase the risk of Covid-19 transmission in boarding schools include one room filled with five to dozens of santri, making it difficult to maintain the distance that is part of the health protocol. The purpose of the Community Service Health Scheme (PbM-SK) is to prevent Covid-19 in pesantren through Information Communication and Education (KIE) activities on improving immunity for the prevention of Covid-19 infection.

Method: The PbM-SK method used is the empowerment of the pesantren community through KIE which is carried out on two partners, namely Pesantren Persis Benda 66 and Pesantren Ibadurrahman. KIE activities at Pesantren Benda 66 were conducted on July 28, 2021, with the number of participants as many as 150 people while the excitement in Pesantren Ibadurrahman was held on August 16, 2021, with the number of participants as many as 150 people. While the excitement in Ibadurrahman Pesantren was held on August 16, 2021, with a total of 30 participants.

Results and discussion: The provision of KIE on improving immunity for the prevention of Covid-19 in Ibadurrahman Pesantren was carried out on MTs and MA students of sons and daughters which was
\end{abstract}

Correspondence: Nur Lina, S.KM., M. Kes (Epid), Universitas Siliwangi, Email nurlina@unsil.ac.id 
carried out in conjunction with TOP (Taaruf Orientasi Pesantren) activities in the new first grade students. Pesantren managers are encouraged to be proactive and coordinate with health services in providing vaccinations in santri. Both partners were given Covid-19 Prevention Kits, namely cloth masks, surgical masks, hand sanitizer, oximeter, vitamin C. Given also banners as educational media, to be a reminder to stay compliant with health protocols.

Conclusion: The implementation of KIE runs smoothly, participants listen enthusiastically. Medical devices have been delivered in the form of cloth masks and surgical masks, hand sanitizers, oximeters, and vitamins.

\section{Keywords : KIE; Covid-19; Pesantren}

\section{PENDAHULUAN}

Coronavirus Disease 2019 (Covid-19) adalah penyakit jenis baru yang belum pernah diidentifikasi sebelumnya pada manusia. Penyebab Covid-19 adalah Severe Acute Respiratory Sindrom-Coronavirus 2 (SARS-CoV 2). Covid-19 dapat ditularkan melalui percikan dahak atau ludah penderita yang berada dalam jarak satu meter pada saat penderita berbicara, batuk ataupun bersin. Dengan demikian, seseorang dapat dengan mudah terinfeksi jika menyentuh benda atau permukaan yang pernah dipegang oleh penderita atau secara langsung berhubungan dengan penderita ${ }^{1}$.

Infeksi SARS-CoV-2 telah dikaitkan dengan spektrum penyakit yang luas yang berkisar dari asimtomatik, ringan hingga parah, dan fatal yaitu kematian. Gejala klinis umum Covid-19 adalah demam, kelelahan, batuk kering, sesak napas, pneumonia, anosmia, dan ageusia ${ }^{2}$. Tanda klinis penyakit Covid-19 muncul setelah masa inkubasi sekitar 5,2 hari yang memakan waktu sekitar 6-41 hari (rata-rata 14 hari) sampai meninggal tergantung usia pasien atau status kekebalan pasien ${ }^{3}$. Umumnya gejala klinis Covid-19 tidak spesifik seperti demam, batuk, dan kelelahan ${ }^{4}$.

Demam dianggap sebagai gejala yang dominan, namun sebenarnya tidak selalu gejala awal infeksi. Gejala lainnya termasuk sakit kepala, produksi dahak, diare, dispnea, dan limfopenia ${ }^{5}$, 2020). Pada awalnya, infeksi terjadi dengan cepat menuju ke organ dalam mengakibatkan gejala seperti akut sindrom gangguan pernapasan (ARDS), syok, gagal ginjal akut, gagal jantung akut, dan bahkan kematian pada kasus yang parah. Pasien mungkin menunjukkan sel darah putih normal atau lebih rendah ${ }^{6}$.

Pemerintah Indonesia menyatakan kondisi kedaruratan Pandemi Covid-19 berdasarkan Keputusan Presiden No.12 th 2020 tentang penetapan bencana non alam penyebaran Covid-19. Perkembangan terkini kasus positif Covid-19 di Indonesia berdasarkan data Komite Penanganan Covid-19 dan Pemulihan Ekonomi Nasional tanggal 2 Mei 2021, kasus terkonfirmasi positif Covid-19 berjumlah 1.677.274 orang dengan angka kematian sebesar 45,796 orang?

Covid-19 ditemukan di hampir setiap provinsi di Indonesia. Pemerintah memutuskan untuk menutup sementara semua sekolah sesuai dengan pola transmisi di setiap wilayah. Kebijakan tersebut tidak hanya dimaksudkan untuk melindungi anak-anak dari Covid-19, selain itu juga membantu mencegah penularan SARS-CoV-2 diantara anak-anak ${ }^{8}$.

Viral load yang ditemukan pada anak-anak adalah sama dibandingkan dengan orang dewasa ${ }^{9}$, tidak ada perbedaan antara tingkat replikasi virus dalam kultur media yang diambil dari tes usap anak-anak dibandingkan untuk tes usap orang dewasa ${ }^{10}$. Oleh karena itu, anak-anak tidak kecil kemungkinannya untuk menularkan penyakit, meskipun mereka mungkin memiliki gejala yang lebih ringan dibandingkan dengan orang dewasa. Pasien dewasa dengan Covid-19 berpotensi menyebarkan virus ke 2-3 orang, studi laporan kasus baru-baru ini di China 
menyatakan bahwa orang muda yang terinfeksi dapat menularkan penyakit ini ke tujuh remaja lainnya ${ }^{11}$. Penularan dapat terjadi sebelum demam atau manifestasi klinis dilaporkan. Studi lain juga menunjukkan bahwa $40 \%$ penularan SARS-CoV-2 terjadi sebelum manifestasi klinis 5 . Berdasarkan sebuah studi di Kanada, pria (terutama lanjut usia) memiliki tingkat keparahan lebih tinggi daripada wanita karena terjadi peningkatan produksi angiotensin enzyme 2 (ACE2) ${ }^{15}$.

Pada tanggal 16 Februari 2021, di Kota Tasikmala muncul Klaster Covid-19 di Pesantren. Sebanyak 380 orang dinyatakan positif Covid-19 yang terdiri dari 159 santri putra, 171 santri putri, dan 50 orang pengajar Pesantren Benda 67 Kota Tasikmalaya. Hal ini berawal dari adanya pembelajaran tatap muka, kemudian 1 santri hilang indra penciuman. Akhirnya 375 Santri Tasikmalaya Positif Covid-19 setelah dilakukan tracing dan tes swab PCR terhadap 832 orang di pesantren Benda 67 Kota Tasikmalaya. Pondok Pesantren Benda 67 Tasikmalaya kemudian ditutup sementara. Kegiatan di lingkungan pesantren dihentikan untuk mencegah penularan Covid-19 12 .

Ada sejumlah hal yang meningkatkan risiko penularan Covid-19 di pondok pesantren. Di antaranya, satu kamar yang bisa diisi lima sampai belasan santri. Kondisi ini menyulitkan prinsip jaga jarak yang menjadi bagian dari protokol kesehatan. Selain itu, penularan berisiko terjadi dengan penggunaan kamar mandi umum. Di sebagian pesantren bahkan masih ditemukan orangtua dan keluarga yang berkunjung sehingga bisa memicu penularan. Jika pengunjung menularkan kepada seorang santri, santri lainnya berpotensi terpapar sebab, intensitas pertemuan santri cukup tinggi, dari pagi hingga malam.

Upaya pencegahan dan pengendalian Covid-19 di pesantren harus dilaksanakan atas dasar kesadaran masyarakat pesantren. Upaya pencegahan dan pengendalian Covid-19 dilakukan melalui penerapan prinsip pencegahan dan pengendalian yang dilakukan dengan meningkatkan daya tahan tubuh santri salah satunya dengan mengonsumsi gizi seimbang, aktivitas fisik minimal 30 menit sehari dan istirahat yang cukup ${ }^{13}$. Suplementasi dengan vitamin D dan vitamin E dapat meningkatkan resistansi terhadap SARS-CoV-2. Vitamin B3 efektif dalam mengurangi cedera pada model hewan dengan kerusakan paru-paru yang diinduksi oleh bleomycin. Vitamin C juga bisa efektif dalam mencegah Covid-19 karena dapat mengurangi keparahan infeksi saluran pernapasan bagian bawah ${ }^{3}$.

Memperkuat sistem kekebalan tubuh dan menciptakan resistensi individu sangat penting untuk memerangi Covid-19. Pendekatan penting untuk meningkatkan kekebalan pribadi termasuk menjaga kesehatan pribadi, mengikuti gaya hidup sehat, dan menjaga asupan makanan yang memadai. Tindakan perlindungan seperti meningkatkan kebersihan pribadi, sering cuci tangan, menjaga jarak dari orang lain (setidaknya satu meter), menghindari pertemuan yang tidak perlu, memakai masker, istirahat yang cukup, menutup wajah saat bersin dan batuk, menghindari menyentuh wajah dengan tangan yang terkontaminasi dan ventilasi yang baik dapat mencegah Covid-19 14 .

Sebagai bagian dari warga negara Indonesia yang berlatar belakang bidang kesehatan khususnya epidemiologi, tim pengusul peduli dan termotivasi untuk membantu pemerintah dalam mencegah terjadinya Covid-19 di Pesantren melalui kegiatan Komunikasi Informasi dan Edulasi (KIE) pada Santri tentang Peningkatan Imunitas untuk Pencegahan Infeksi Covid 19 melalui kegiatan Pengabdian Masyarakat Skema Kesehatan (PbM-SK). KIE pada santri merupakan bagian dari manajemen pencegahan terhadap terjadinya penyakit menular khususnya Covid 19.

Pelaksanaan kegiatan Pengabdian Masyarakat Skema Kesehatan (PbM-SK) dilakukan bekerjasama dengan 2 (dua) mitra. Mitra1 yaitu Pondok Pesantren 67 Benda yang terletak di J1 Benda Kecamatan Cipedes Kota Tasikmalaya dan Mitra 2 adalah SMA Islam terpadu (SMA IT) 
Ibadurrohman yang terletak di jalan Jl Cisumur Karsamenak Kecamatan Kawalu Kota Tasikmalaya. Alasan pemilihan mitra 1 didasarkan data ditemukannya klaster pesantren pada Pesantren Benda 67 pada tanggal 16 Februari 2021, dengan jumlah Santri dan pengurus yang terkonfirmasi positif sebanyak 380 orang. Alasan pemilihan mitra 2 karena SMA Islam terpadu (SMA IT) Ibadurrohman pernah ditemukan adanya kakak santri positif Covid-19 dan kontak dangan santri, sehingga santri tersebut harus diisolasi.

Hasil pertemuan dan diskusi dengan mitra, disepakati bahwa upaya pemecahan masalah akan dilakukan dengan; memberikan Komunikasi Informasi dan Edukasi (KIE) pada santri tentang peningkatan imunitas untuk pencegahan infeksi Covid-19. Mengedukasi siswa dalam aksi gerakan hidup bersih sehat mengendalikan pandemi Covid-19 melalui protokol kesehatan dengan $5 \mathrm{M}$ yaitu memakai masker, mencuci tangan pakai sabun dan air mengalir, menjaga jarak, menjauhi kerumunan, serta membatasi mobilisasi dan interaksi. Memberikan masker, sabun cuci tangan, hand sanitizer, oksimeter dan Vitamin

\section{METODE}

Upaya yang dilakukan oleh tim pengusul agar mitra meningkat pengetahuannya tentang imunitas untuk pencegahan infeksi Covid-19 sehingga mau melakukan tindakan untuk meningkatakan imunitas untuk pencegahan infeksi Covid 19. Prinsip pembelajaran menekankan bahwa transfer ipteks dimulai dengan transfer knowledge, perubahan persepsi atau sikap dan mengadopsi melalui praktek.

Transfer ipteks tersebut meliputi tahapan kegiatan ; (1) transfer knowledge yaitu memberikan informasi dengan mendengarkan, menyimak, dan menanggapi. Metode yang digunakan pada tahap ini adalah memberikan penyuluhan tentang Peningkatan Imunitas untuk Pencegahan Infeksi Covid-19 dengan materi mengenai sistem imun, cara meningkatkan sistem imun (2) perubahan persepsi, mitra menerima informasi melalui mengamati, demonstrasi, dan penggunaan media atau alat peraga. Metode yang digunakan pada tahap ini adalah pemberian media penyuluhan (3) Adopsi : mitra menerima informasi dengan berlatih dan menerapkan.

Metode yang digunakan pada tahap ini adalah pemberdayaan masyarakat pesantren. Pemberdayaan masyarakat pesantren adalah proses untuk meningkatkan pengetahuan, kesadaran, dan kemampuan masyarakat pesantren agar berperan aktif dalam upaya pencegahan dan pengendalian Covid-19 yang dilaksanakan dengan cara fasilitasi proses pemecahan masalah melalui pendekatan edukatif dan partisipatif serta memperhatikan kebutuhan potensial dan sosial budaya setempat. Meningkatkan literasi kesehatan pada santri dilakukan dengan: meningkatkan kapasitas pengetahuan santri tentang imunitas untuk pencegahan infeksi Covid-19; membuat media Komunikasi, Informasi, dan Edukasi (KIE); melakukan KIE;

Tujuan penyampaian informasi pada setiap tahapan adalah meningkatkan pengetahuan santri terhadap pencegahan infeksi Covid-19. Pemberdayaan santri bertujuan agar pengetahuan dan pemahaman kepada mitra mengenai imunitas untuk pencegahan infeksi Covid-19 menjadi kebiasaan baik (sustainable) yang dilakukan meskipun PbM-SK telah selesai, dilakukan dengan penyuluhan yang bertujuan agar mitra bersikap atau berpersepsi baik. Adopsi dilakukan untuk memastikan mitra mampu berperilaku sehat untuk meningkatkan imunitas dalam aktivitas seharihari santri. Melalui tahapan-tahapan tersebut diharapkan proses transfer ipteks yang diberikan bisa sustainable, menjadi kebiasaan yang dilakukan oleh mitra.

Pondok pesantren 67 Benda terletak di Jl. Benda Kecamatan Cipedes Kota Tasikmala dan SMA Islam Terpadu (SMA IT) Ibadurrohman yang terletak di Jl. Cisumur Karsamenak 
Kecamatan Kawalu Kota Tasikmalaya menjadi mitra sasaran untuk melakukan kegiatan pengabdian pada masyarakat dalam bentuk pemanfaatan hasil penelitian di bidang kesehatan, penerapan teknologi tepat guna yang dilakukan oleh para dosen, yang dapat langsung dimanfaatkan dalam upaya-upaya mencegah penyebaran Covid-19. Secara garis besar, proses yang dilakukan untuk membantu mitra agar meningkat pengetahuannya tentang imunitas untuk mencegah infeksi Covid-19 dilakukan dengan memberikan peralatan kesehatan berupa masker, hand sanitizer dan sabun cuci tangan yang diserahkan kepada mitra agar dapat dimanfaatkan secara optimal untuk pencegahan pandemi Covid-19, digambarkan sebagai berikut :

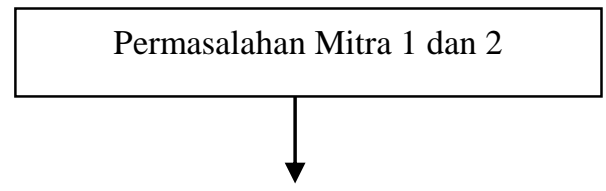

1. Adanya risiko penularan Covid-19 pada santri

2. Kurangnya Fasilitas: masker, sabun dan hand sanitizer, vitamin $\mathrm{C}$

3. Belum tersosialisasikannya informasi mengenai Covid-19 dan cara pencegahannya

SOLUSI
"Komunikasi Informasi dan Edulasi (KIE) pada Santri Tentang Peningkatan Imunitas
untuk Pencegahan Infeksi Covid-19”.
1. KIE pada santri tentang peningkatan imunitas untuk mencegah Covid-19.
2. Pemberian masker, sabun serta hand sanitizer, masker dewasa dan anak anak
3. KIE pentingnya 5M untuk mencegah Covid-19

\section{HASIL DAN PEMBAHASAN}

\section{Pemberian KIE tentang Peningkatan Imunitas untuk Pencegahan Covid-19}

Kegiatan pemberian KIE dilakukan pada kedua mitra yaitu Pesantren Persis Benda 66 dan Pesantren Ibadurrahman. Pemberian KIE tentang peningkatan imunitas untuk pencegahan Covid19 di Pesantren Pesantren Persis Benda 66 dilaksanakan pada siswa MTs dan MA putra dan putri yang dilaksanakan bersamaan dengan kegiatan TOP (Taaruf Orientasi Pesantren) pada santri baru kelas satu, dilaksanakan pada tanggal 28 Juli 2021. KIE pada santri kelas satu MTs putra dilaksanakan di GOR pesantren putra, dan santri kelas satu MA putra dilaksanakan di ruang aula MA, sedangkan santri putri dilaksanakan di ruang aula putri, dilaksanakan secara luring dengan tetap mempertahankan protokol kesehatan. Jumlah seluruh santri yang mengikuti KIE sebanyak 150 orang. 
Anggota tim PPM yang mengisi materi dilakukan swab antigen terlebih dahulu agar bisa masuk pondok, dan kegiatan pemberian KIE dilaksanakan dengan tetap memperhatikan protokol kesehatan. Adapun untuk kegiatan KIE pada santri siswa MA Pesantren Ibadurrahman dilaksanakan secara daring melalui zoom, dan santri yang merupakan siswa dan siswi MA melaksanakannya di laboratorium komputer sekolah dengan jumlah peserta sebanyak 30 orang.

Pelaksanaan KIE berjalan dengan lancar, peserta menyimak materi dengan antusias. Hal ini terlihat dengan banyaknya pertanyaan peserta pada sesi diskusi. Topik pertanyaan sebagian besar terkait dengan vaksinasi Covid-19, yang merupakan upaya untuk meningkatkan kekebalan atau sistem imun spesifik terhadap infeksi Covid-19. Diantaranya adalah tentang kekhawatiran adanya efek samping pasca vaksinasi, tentang daya lindung vaksinasi terhadap terjadinya infeksi, tentang syarat vaksinasi untuk masyarakat yang memiliki penyakit penyerta (komorbid) dan tentang kekebalan kelompok (herd immunity).

\section{Advokasi pada Pengelola Pesantren tentang Pentingnya Vaksinasi}

Vaksinasi Covid-19 saat ini tidak hanya menyasar pada petugas kesehatan (medis dan non medis), tetapi juga pada kelompok masyarakat lainnya, termasuk kelompok lansia, dewasa, hingga anak 12-18 tahun. Seiring perkembangan kondisi pandemi dari waktu ke waktu dan hasil uji coba vaksin Covid-19, WHO melakukan update tentang batasan usia penduduk yang boleh mendapatkan vaksinasi. Rekomendasi terakhir adalah pemberian vaksinasi Covid-19 untuk anak berusia 12-18 tahun. Hal ini menjadi aspek yang sangat penting, sejalan dengan upaya pelaksanaan pembelajaran tatap muka terbatas (PTMT) di sekolah. Ketika sebagian besar anak sekolah sudah di vaksinasi, maka rantai penularan infeksi di sekolah akan berkurang risikonya. Apalagi pada situasi siswa di pesantren, dimana seluruh santri beraktifitas setiap hari, sehingga jika santri diberikan vaksinasi, maka akan mengurangi risiko terjadinya infeksi Covid-19 di lingkungan pesantren, yang juga akan mengurangi kecemasan keluarga santri di rumah.

Pengelola pesantren didorong untuk terlibat secara pro aktif dan berkoordinasi dengan pelayanan kesehatan setempat dalam pemberian vaksinasi pada santri, agar dapat segera melaksanakan kegiatan vaksinasi di pesantren. Juga mendorong civitas akademika pesantren yang lain (guru/ustadz, pengurus, kantin, satpam, dll) juga agar melakukan vaksinasi sehingga seluruh civitas pesantren memiliki kekebalan spesifik terhadap Covid-19. Selain itu, penting pula untuk melakukan pendekatan pada orangtua santri agar memberikan izin sehingga anaknya yang di pesantren memperoleh vaksinasi, agar cakupan imunisasi minimal 70 persen terpenuhi dan terbentuk kekebalan kelompok. Meski demikian, vaksinasi tidak berarti pula akan seratus persen terhindar dari infeksi Covid-19, sehingga penerapan protokol kesehatan dalam setiap aktivitas masih tetap perlu dilakukan.

\section{Pembagian Kit Pencegahan Covid-19}

Sebagai bagian dari kegiatan pengabdian masyarakat, kedua mitra diberikan sejumlah sarana kesehatan untuk pencegahan Covid-19 diantaranya adalah masker kain dan masker bedah, hand sanitizer, oksimeter, vitamin C. Diharapkan bantuan yang diberikan bisa mendorong pihak pesantren dalam penerapan protokol kesehatan. Diberikan juga banner tentang protokol pencegahan Covid-19 di pesantren sebagai media edukasi, yang disimpan di bagian depan pesantren untuk menjadi pengingat agar semua civitas akademika pesantren tetap patuh dalam menjalankan protokol kesehatan. 


\section{Luaran yang Dicapai}

Kegiatan ini dilakukan publikasi melalui Surat Kabar Radar Tasikmalaya dan dimuat pada hari berikutnya. Selain itu disusun juga draf jurnal publikasi.
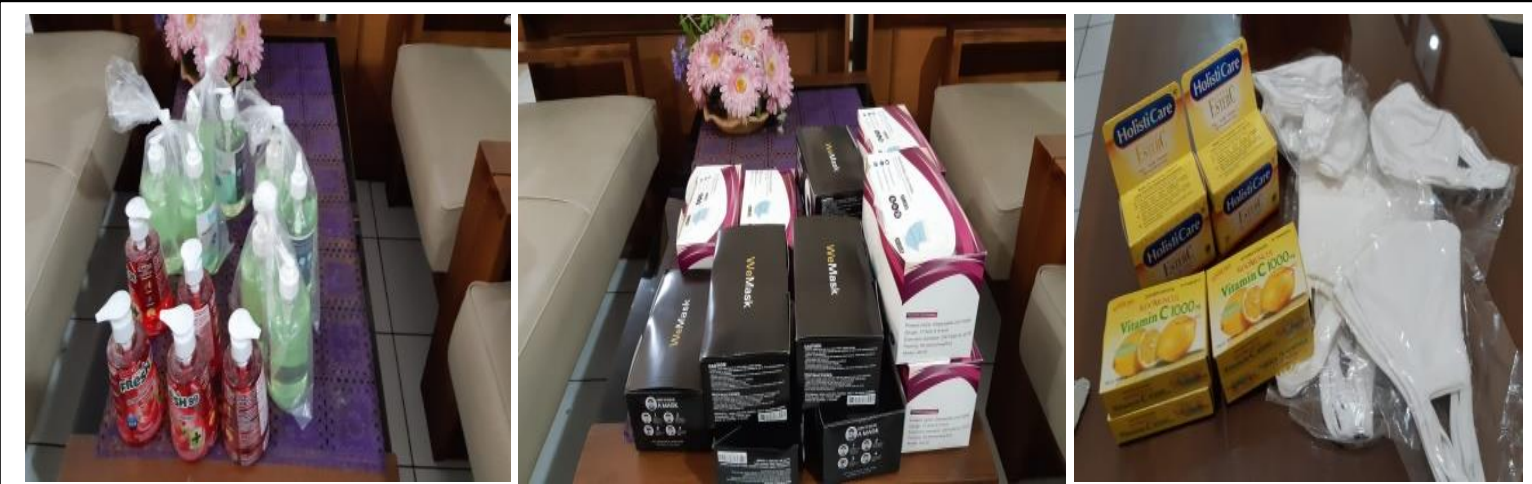

Gambar 1. Pemberian Alat Kesehatan untuk Menunjang Penerapan Protokol Kesehatan Pencegahan Infeksi Covid 19
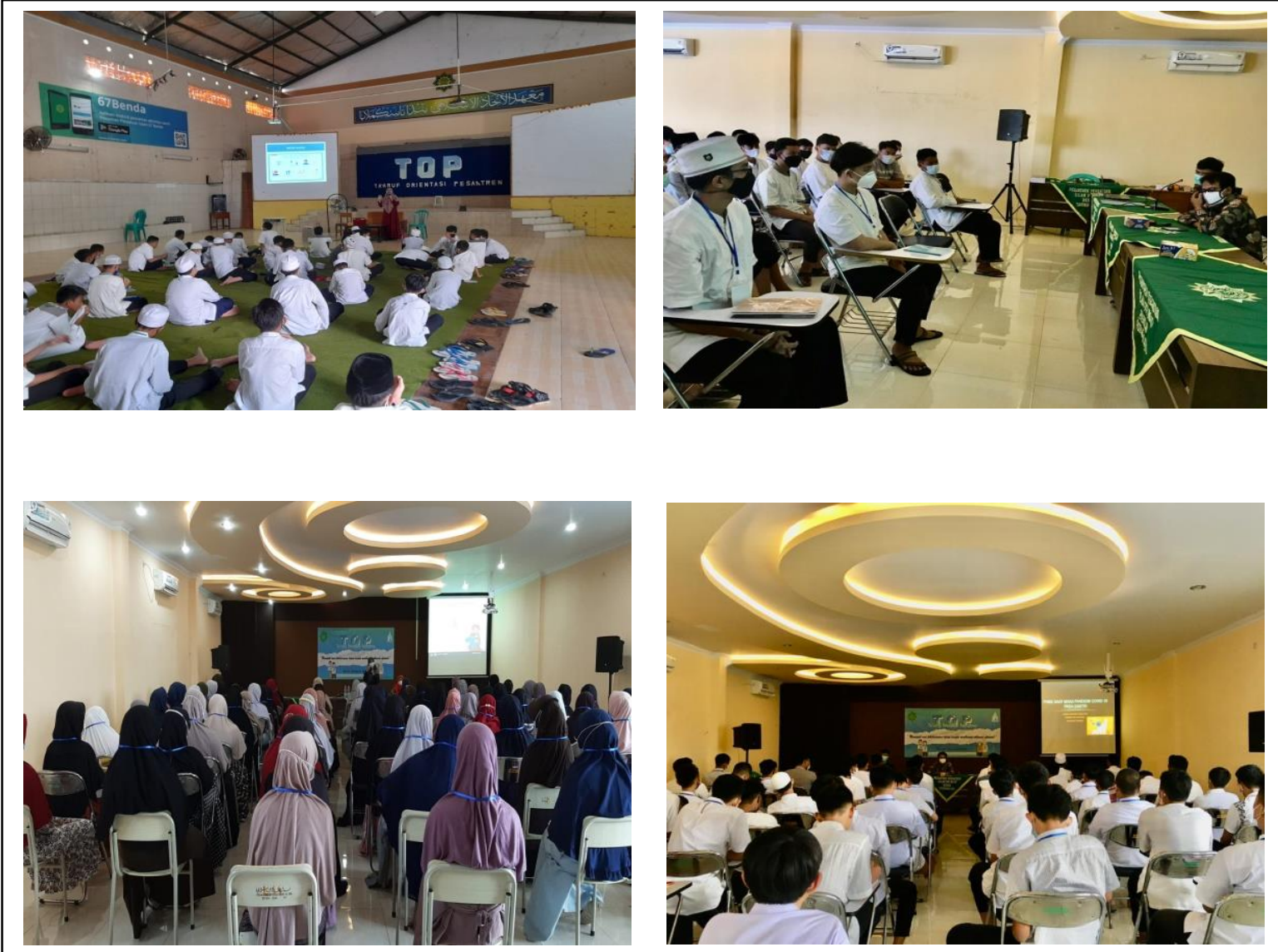

Gambar 2. Pemberian Edukasi di Pesantren Persis Benda 67 

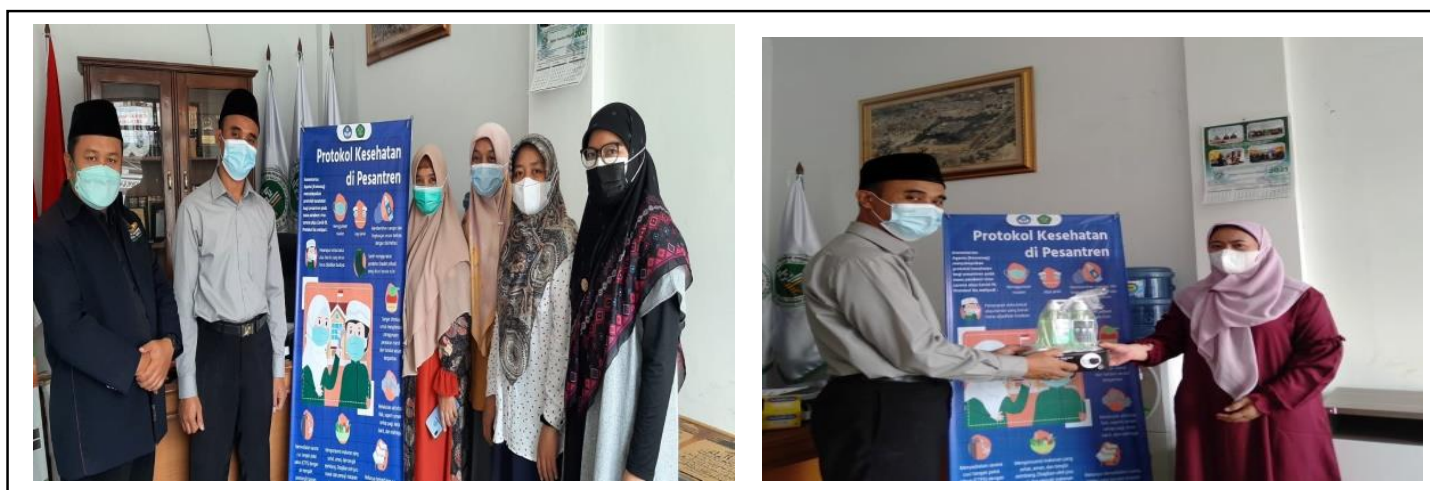

Gambar 3.Advokasi dan Penyerahan Media KIE (Banner) dan Kit Pencegahan Covid-19 di Pesantren Ibadurrahman

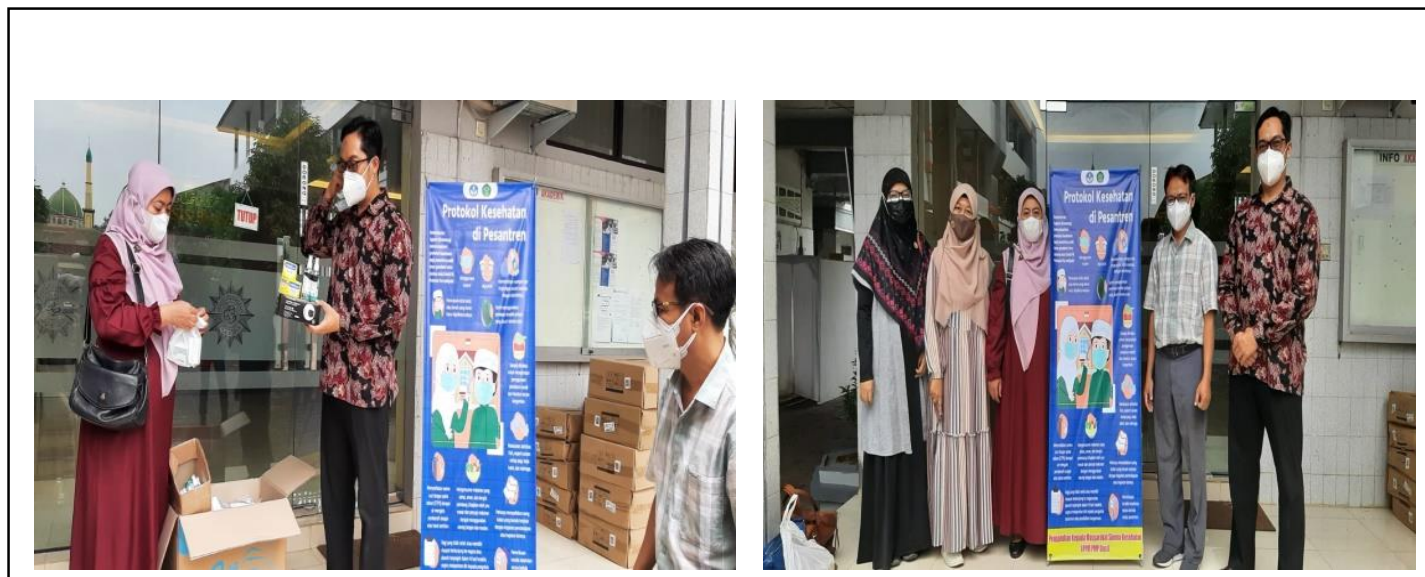

Gambar 4. Advokasi dan Penyerahan Media KIE (Banner) dan Kit Pencegahan Covid -19 di Pesantren Persis Benda
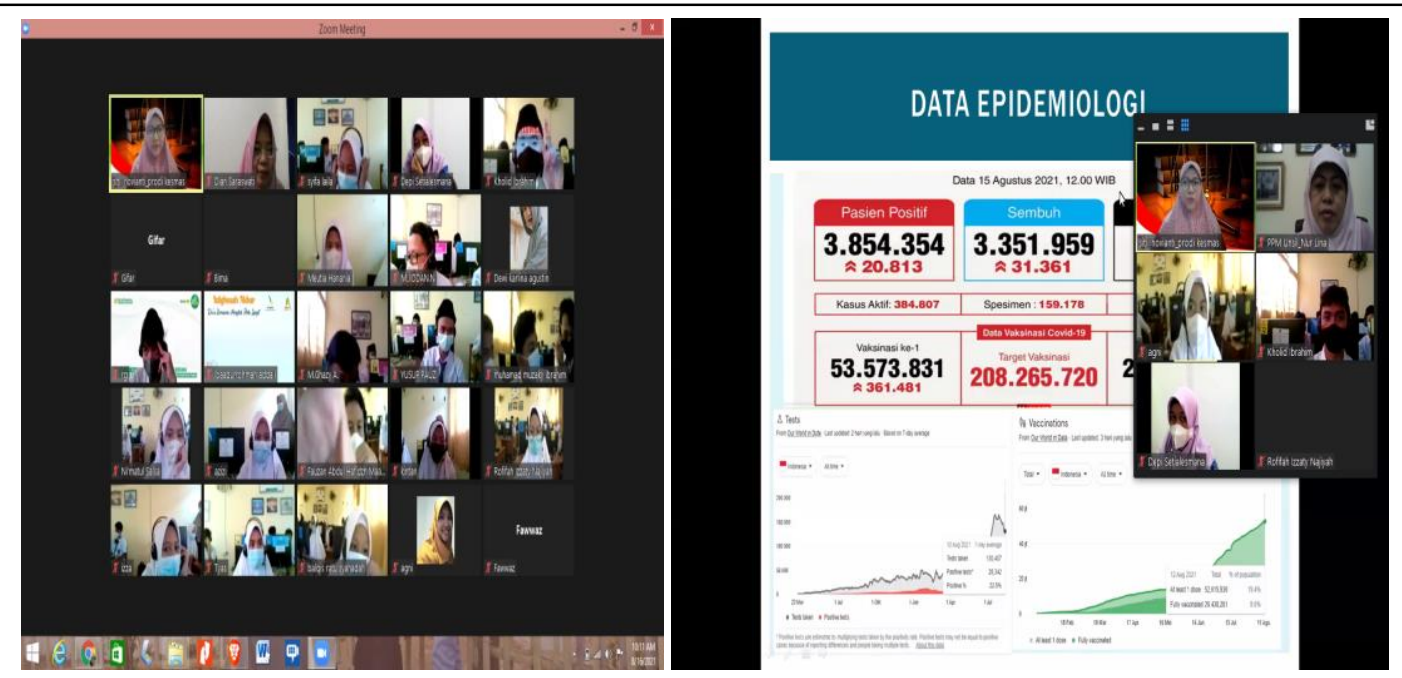

Gambar 5.Pemberian Edukasi Pencegahan Covid -19 di Pesantren Ibadurrahman 


\section{KESIMPULAN}

Telah dilakukan pemberian KIE kepada santri MTs dan MA di Pesantren Ibadurrahman dan Pesantren Persis Benda kota Tasikmalaya. Telah diberikan media KIE berupa banner dan materi edukasi tentang protokol kesehatan di pesantren dan peningkatan imunitas untuk pencegahan infeksi Covid-19. Telah disampaikan sejumlah alat kesehatan untuk menunjang penerapan protokol kesehatan berupa masker kain dan masker bedah, hand sanitizer dan oksimeter

\section{UCAPAN TERIMA KASIH}

Penulis mengucapkan terima kasih kepada Lembaga Penelitian dan Pengabdian masyarakat Universitas Siliwangi yang telah memberikan hibah pengabdian Pengabdian Bagi Masyarakat Skema Kesehatan (PbM-SK), pimpinan Pondok Pesantren Ibadurrahman, pimpinan Pondok Pesantren Persis Benda, mahasiswa Program Studi Kesehatan Masyarakat yang ikut terlibat dalam kegiatan ini

\section{DAFTAR PUSTAKA}

1. WHO. WHO Director-General's opening remarks at the media briefing on COVID-19-11 March 2020 2020March 11 [Available from: https://www.who.int/dg/speeches/detail/who-director-general-sopening-remarks-at-the-media-briefing-on-covid-19---11-march-2020.

2. Guan WJ, Ni ZY, Hu Y, Liang WH, Ou CQ, He JX, et al. Clinical characteristics of coronavirus disease 2019 in China. N Engl J Med. 2020 Apr 30;382(18):1708-20

3. Wang L-s, Wang Y-r, Ye D-w, Liu Q-q. A review of the 2019 Novel Coronavirus (COVID-19) based on current evidence. International Journal of Antimicrobial Agents. 2020:105948.

4. Li Q, Guan X, Wu P, et al. Early transmission dynamics in Wuhan, China, of novel coronavirusinfected pneumonia. N Engl J Med. 2020;382(13):1199-1207. doi:10.1056/NEJMoa2001316

5. Huang L, Zhang X, Zhang X, et al. Rapid Volume 4(1) April 2021, infectivity in a cluster of youngsters aged 16- 23 years outside Wuhan and characteristics of young patients with COVID-19: a prospective contact-tracing study. J Infect. 2020;80(6):e1- e13. doi:10.1016/j.jinf.2020.03.006

6. Ai T, Yang Z, Hou H, et al. Correlation of Chest CT and RT-PCR Testing in Coronavirus Disease 2019 (COVID-19) in China: A Report of 1014 Cases. Radiology. 2020:200642. doi:10.1148/ radiol.2020200642.

7. KPCPEN, 2021, https://covid19.go.id/p/berita/data-vaksinasi-covid-19-update-2-mei-2021

8. Kelvin AA, Halperin S. COVID-19 in children: the link in the transmission chain. Lancet. 2020;20:633-634. doi:10.1016/S1473- 3099(20)30236-X

9. Jones TC, Mühlemann B, Veith T, et al. An analysis of SARS-CoV-2 viral load by patient age. medRxiv. 2020. doi:10.1101/2020.06.08.20125484

10. L'Huillier AG, Torriani G, Pigny F, Kaiser L, Eckerle I. Shedding of infectious SARS-CoV-2 in symptomatic neonates, children and adolescents. medRxiv. 2020. doi:10.1101/2020.04.27.20076778

11. Liu Y, Yan L-M, Wan L, et al. Viral dynamics in mild and severe cases of COVID-19. Lancet Infect Dis. 2020. 10.1016/S1473-3099(20)30232-2. [PMC free article] [PubMed]

12. Kompas, 2021 https://regional.kompas.com/read/2021/02/17/10472421/muncul-klaster-pesantren-ditasikmalaya-380-orang-positif-covid-19?page=all

13. Kemenkes 2020, Keputusan Menteri Kesehatan Republik Indonesia Nomor Hk.01.07/Menkes/2322/2020 Tentang Panduan Pemberdayaan Masyarakat Pesantren Dalam Pencegahan Dan Pengendalian Coronavirus Disease 2019 (Covid-19) di Pesantren.

14. Lu R, Zhao X, Li J, et al. Genomic characterisation and epidemiology of 2019 novel coronavirus: implications for virus origins and receptor binding. Lancet. 2020;395(10224):565-574. doi:10.1016/S0140- 6736(20)30251-8 
15. Viveiros A, Gheblawi M, Aujla P, Sosnowski D, Seubert J, Kassiri Z et al. Sex- and age-specific regulation of ACE2: Insights into severe COVID-19 susceptibility. Journal of Molecular and Cellular Cardiology. 2021;164:13-16 